\title{
Studies on Engineering and Microstructure Properties of Chromium(VI)- Contaminated Soil
}

\author{
Yuan Yuan $\mathrm{Li}^{*}$ and Ting Ting Zhang**(***)† \\ *Qingdao University of Technology, Qingdao, 266033, China \\ **Wisdri City Environment Protection Engineering Limited Company, Wuhan, 430205, China \\ ***Wuchang Shouyi University, School of Urban Construction, Wuhan 430064, China \\ †Corresponding author: Ting Ting Zhang; ttz_dshb@163.com; ztt_cersm@163.com
}

Nat. Env. \& Poll. Tech.

Website: www.neptjournal.com

Received: 02-02-2020

Revised: 25-02-2020

Accepted: 02-05-2020

Key Words:

$\mathrm{Cr}(\mathrm{VI})$-contaminated soil

Physicochemical properties

Engineering properties

Microstructure

\begin{abstract}
Hexavalent chromium [Cr( $\mathrm{VI})]$-contaminated soils have introduced a serious problem in $\mathrm{China}$. $\mathrm{Cr}(\mathrm{VI})$ is hazardous to both the environment and public health and may degrade the engineering properties of soils. Accordingly, the effects of $\mathrm{Cr}(\mathrm{VI})$ on the physicochemical, mechanical, and microstructure properties of Chinese clay were investigated in this study. Results show that $\mathrm{Cr}(\mathrm{VI})$ had a considerable negative effect on the physicochemical, mechanical, and microstructure properties of soil. Specifically, $\mathrm{Cr}(\mathrm{VI})$ changed the physicochemical properties and degraded the mechanical properties of soil, led to the aggregation of soil particles, and created a large void space. $\mathrm{Cr}(\mathrm{VI})$ also changed the mineral composition of the soil and converted clay minerals into calcite. The changes in the microstructure and mineral composition of the soil were the primary reasons for the differences in the engineering properties of $\mathrm{Cr}(\mathrm{VI})$-contaminated soil.
\end{abstract}

\section{INTRODUCTION}

The heavy metal contamination of soil in China has become severe due to the improper waste disposal practices and accidental chemical spills in the country (Wei et al. 2015). Heavy metals are hazardous to the environment and public health and may degrade the mechanical properties of soils, thereby placing engineering safety at risk (Du et al. 2013). Many studies have shown that the engineering properties of contaminated soils are closely related to the type and content of heavy metals. Zhang et al. (2014) studied the permeability behaviour of copper-contaminated clay and set a $0.5 \mathrm{~g} / \mathrm{L}$ threshold for the influence of copper concentration on permeability. They found that the hydraulic conductivity and void ratio of contaminated clay decrease when the copper concentration is lower than $0.5 \mathrm{~g} / \mathrm{L}$. Li et al. (2015) showed that $\mathrm{Pb}(\mathrm{NO})_{3}$ solutions can increase the maximum dry density and cohesion of typical clay in China yet reduce its optimum moisture content and swelling. This trend becomes more obvious at higher $\mathrm{Pb}(\mathrm{NO})_{3}$ concentrations. Liu et al. (2016) showed that $\mathrm{Zn}(\mathrm{NO})_{3}$ solutions decrease the void ratio and compression index of kaolin. However, when the $\mathrm{Zn}(\mathrm{NO})_{3}$ solutions exceed $0.02 \mathrm{~mol} / \mathrm{L}$, the void ratio of kaolin is nearly unchanged. Chen et al. (2014) studied the strength properties and development of zinc- and cadmium-contaminated soil and found that zinc and cadmium degrade the strength of the soil and that the strength of cadmium-contaminated soil is significantly lower than that of zinc-contaminated soil.

Previous studies show that the engineering properties of contaminated soils are closely related to the type and content of heavy metals. Many of these studies have focused on the engineering properties of soil contaminated with low-valence heavy metals, such as lead $(\mathrm{Pb})$, zinc $(\mathrm{Zn})$, copper $(\mathrm{Cu})$, and cadmium $(\mathrm{Cd})$, yet no peer-reviewed study has examined the engineering properties and microstructure development of soil contaminated with high-valence heavy metals, such as chromium $(\mathrm{Cr})$, and no consensus has been reached regarding the effect of these high-valence heavy metals on the engineering properties and microstructure of soil. Systematical analyses on this subject are also lacking.

Hexavalent chromium [Cr(VI)] has become a source of environmental concern in China and has been classified by Chinese officials as the first major heavy metal that needs to be managed and controlled (Zhang et al. 2018). Accordingly, a series of tests, including $\mathrm{pH}$, specific gravity, particle size distribution, compaction, strength, permeability, and shear strength tests, were conducted in this paper to study the effect of different content of $\mathrm{Cr}()$ on the engineering and microstructure properties of Chinese clay. The changes in the structure of $\mathrm{Cr}(\mathrm{VI})$-contaminated soil were interpreted by performing nitrogen adsorption (BET), scanning electron 
microscope (SEM) observations, and detailed mineralogical (XRD) tests. The findings of this work can facilitate the remediation and reuse of $\mathrm{Cr}(\mathrm{VI})$-contaminated soil.

\section{MATERIALS AND METHODS}

\section{Cr(VI)-Contaminated Soil}

Given its representativeness and repeatability, $\mathrm{Cr}(\mathrm{VI})$ contaminated soil simulated by Chinese clay and $\mathrm{K}_{2} \mathrm{Cr}_{2} \mathrm{O}_{7}$ was used in this study (Zhang et al. 2019). Soil samples with a $\mathrm{Cr}(\mathrm{VI})$ content of $0,500,1000,5000$, and $10000 \mathrm{mg} / \mathrm{kg}$ were used to represent the universal concentration for $\mathrm{Cr}(\mathrm{VI})-$ contaminated soil in China (Zhang et al. 2009, Wang et al. 2014). The contaminated soil was mixed evenly and braised for 180 days under standard curing conditions $\left(20^{\circ} \mathrm{C}, 95 \%\right.$ humidity) to allow $\mathrm{K}_{2} \mathrm{Cr}_{2} \mathrm{O}_{7}$ and the soil to react adequately and to obtain an ageing contaminated soil.

\section{Methods}

The $\mathrm{Cr}(\mathrm{VI})$-contaminated soil was subjected to $\mathrm{pH}$, specific gravity, compaction, strength, permeability, and shear strength tests following the relevant Chinese standards (GB/ T50123,1999). For each test, the samples were prepared in triplicate and were denoted by $\mathrm{C}=0,500,1000,5000$, and $10000 \mathrm{mg} / \mathrm{kg}$, where C represents their $\mathrm{Cr}(\mathrm{VI})$ content.

The changes in the crystalline phases of the $\mathrm{Cr}(\mathrm{VI})$ contaminated soil was determined by using a D8 Advance $\mathrm{X}$-ray diffractometer, whereas the changes in the surface area and pore size were determined by using a surface area analyser (Nova 1000e series, USA). Microscopic observations were obtained by SEM.

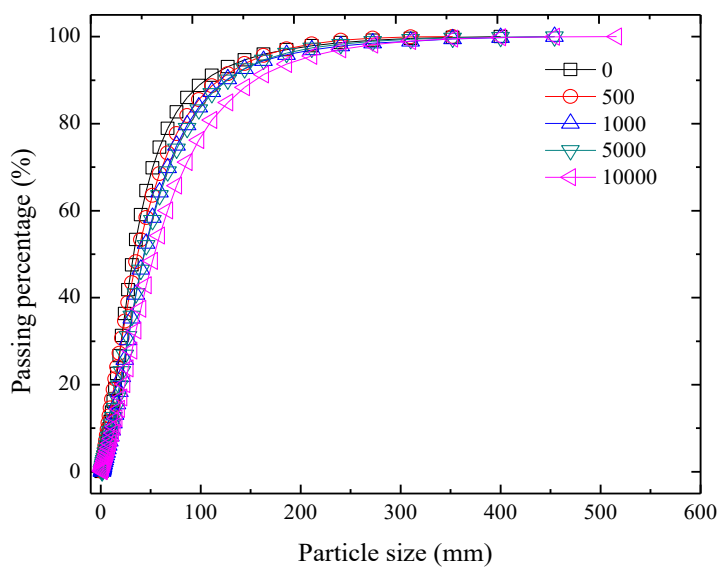

Fig. 2: Effect of chromium content on the grain-size distribution of the soil.

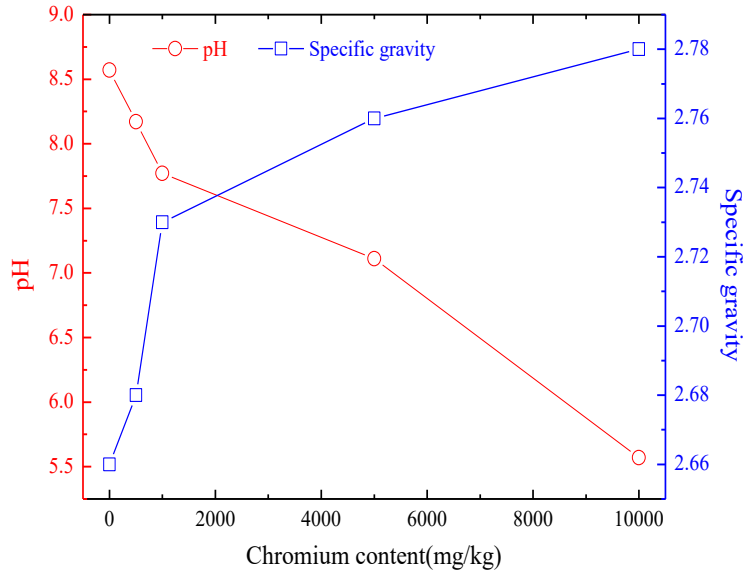

Fig. 1: Effect of chromium content on the $\mathrm{pH}$ and specific gravity of soil.

\section{RESULTS AND ANALYSIS}

\section{pH and Specific Gravity}

The effect of $\mathrm{Cr}(\mathrm{VI})$ content on the $\mathrm{pH}$ and specific gravity of the soil is shown in Fig. 1. An increase in $\mathrm{Cr}(\mathrm{VI})$ content from $0 \mathrm{mg} / \mathrm{kg}$ to $10000 \mathrm{mg} / \mathrm{kg}$ increased the specific gravity of the soil from 2.66 to 2.78 and reduced its $\mathrm{pH}$ from 8.57 to 5.51 . The increase in soil specific gravity was attributed to the reaction of $\mathrm{Cr}(\mathrm{VI})$ with the clay mineral of soil via ion exchange and complex reaction, which embedded the $\mathrm{Cr}(\mathrm{VI})$ onto the soil particle surface and released low-density organic matter (Wu et al. 2014). Meanwhile, the reduction in $\mathrm{pH}$ could be attributed to the release of $\mathrm{H}^{+}$during the ion exchange between the soil particle and $\mathrm{Cr}(\mathrm{VI})$ (MirandaTrevino et al. 2003).

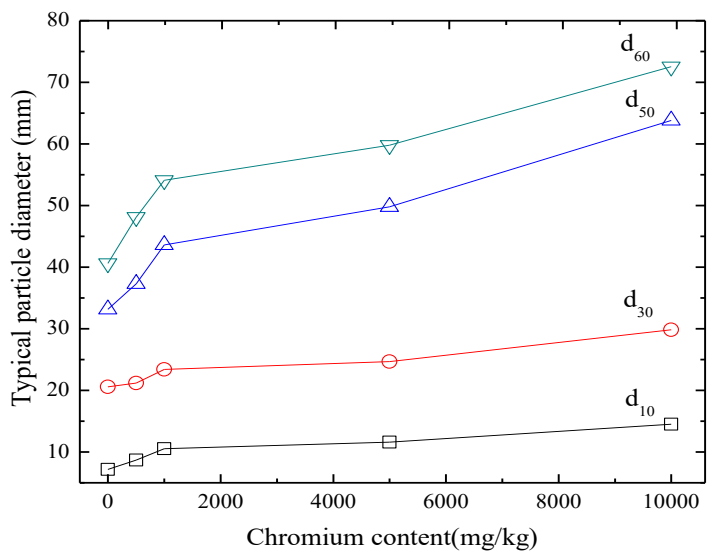

Fig. 3: Effect of chromium content on the typical particle diameter of soil. 


\section{Particle Size}

The variations in the grain-size distribution and typical particle diameter of soil with different $\mathrm{Cr}(\mathrm{VI})$ contents are shown in Figs. 2 and 3. The soil particle size increased along with $\mathrm{Cr}(\mathrm{VI})$ content, which subsequently shifted the particle size distribution curve rightward and increased the typical soil particle diameter. The $\mathrm{d}_{10}, \mathrm{~d}_{30}, \mathrm{~d}_{50}$, and $\mathrm{d}_{60}$ of the soil increased from 7.18, 20.58, 33.21, and $40.63 \mathrm{~mm}$ to 14.53 , $29.84,63.84$, and $72.53 \mathrm{~mm}$, respectively. The changes in the soil particle size could be attributed to the aggregation of soil permeated with $\mathrm{Cr}(\mathrm{VI})$ due to reduced DDL thickness of the soil particles (Morvan et al.1994).

\section{Compaction}

The effect of $\mathrm{Cr}(\mathrm{VI})$ content on the maximum dry density and optimum moisture content of the soil is shown in Fig. 4. The experimental data indicated that $\mathrm{Cr}(\mathrm{VI})$ could increase the maximum dry density of soil and decrease its optimum moisture content. The maximum dry density increased from $1.68 \mathrm{~g} / \mathrm{cm}^{3}$ to $1.73 \mathrm{~g} / \mathrm{cm}^{3}$, whereas the optimum moisture content decreased from $23.63 \%$ to $21.13 \%$. $\mathrm{Cr}$ (VI) also resulted in the aggregation of soil particles, thereby increasing the maximum dry density. The decrease in soil particle size could also be attributed to the reduced DDL thickness of the soil particle, water holding capacity, and optimum water content ( $\mathrm{Li}$ et al. 2015).

\section{Unconfined Compression Strength}

The effect of $\mathrm{Cr}(\mathrm{VI})$ content on the soil stress-strain curves is shown in Fig. 5. Generally, the shapes of these stress-strain curves considerably differed between low and high $\mathrm{Cr}(\mathrm{VI})$ content conditions. To illustrate, when the $\mathrm{Cr}(\mathrm{VI})$ content was less than $500 \mathrm{mg} / \mathrm{kg}$, the contaminated soils exhibited brittleness as manifested in the rapid reduction in their postpeak stress along with an increasing strain. Similar behaviour

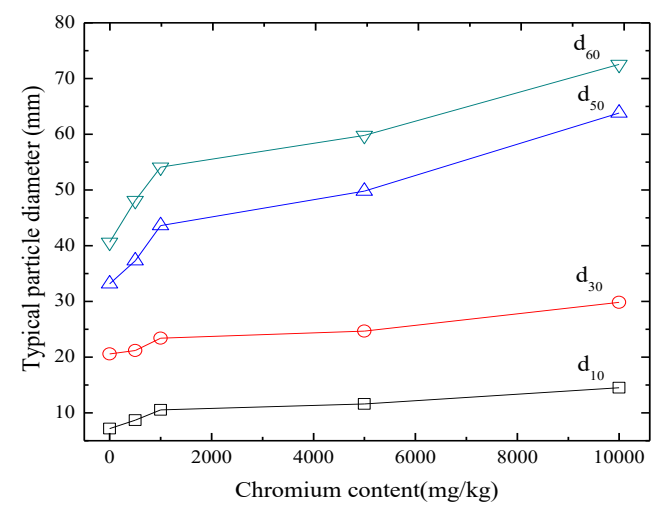

Fig. 4: Effect of chromium content on the maximum dry density and optimum moisture content of the soil. has been reported in natural soils (Horpibulsk 2011). When the $\mathrm{Cr}(\mathrm{VI})$ content exceeded $500 \mathrm{mg} / \mathrm{kg}$, the contaminated soil behaved similarly to a ductile material with a gradual decrease in its post-peak stress along with a decreasing strain. Fig. 6 shows the variations in unconfined compression strength $\left(\mathrm{q}_{\mathrm{u}}\right)$ and failure strain $\left(\varepsilon_{\mathrm{f}}\right)$ along with $\mathrm{Cr}(\mathrm{VI})$ content. The $\mathrm{q}_{\mathrm{u}}$ of the soil decreased from $0.44 \mathrm{MPa}$ to $0.21 \mathrm{MPa}$, whereas its $\varepsilon_{\mathrm{f}}$ decreased from $2.84 \%$ to $8.35 \%$. qu slightly changed when the $\mathrm{Cr}(\mathrm{VI})$ content was less than $500 \mathrm{mg} / \mathrm{kg}$ yet considerably decreased when the $\mathrm{Cr}(\mathrm{VI})$ content exceeded $500 \mathrm{mg} / \mathrm{kg}$. The lowest $\mathrm{q}_{\mathrm{u}}$ and highest $\varepsilon_{\mathrm{f}}$ were obtained when the $\mathrm{Cr}(\mathrm{VI})$ content increased to $10000 \mathrm{mg} / \mathrm{kg}$. Fig. 6 shows that the $\mathrm{Cr}(\mathrm{VI})$ content is a crucial factor that controls the strength of $\mathrm{Cr}(\mathrm{VI})$-contaminated soils. Therefore, at a specific curing time, a linear function indicated by Eqs. (1) and (2) was used to describe the relationship between the strength properties $\left(\mathrm{q}_{\mathrm{u}}\right.$ and $\left.\varepsilon_{\mathrm{f}}\right)$ and $\mathrm{Cr}(\mathrm{VI})$ content of the soil.

$$
\begin{aligned}
\mathrm{q}_{\mathrm{uc}} & =-2.12 \mathrm{C}+\mathrm{q}_{0} \\
\varepsilon_{\mathrm{fc}} & =5.47 \mathrm{C}+\varepsilon_{0}
\end{aligned}
$$

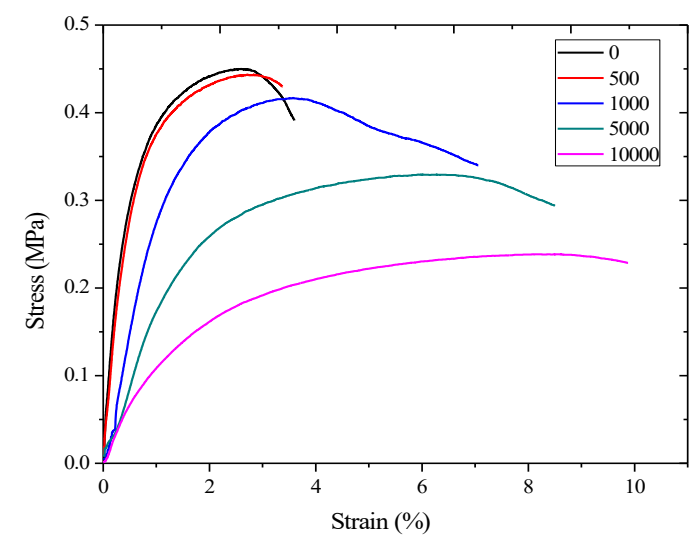

Fig. 5: Effect of chromium content on the stress-strain curves of soil.

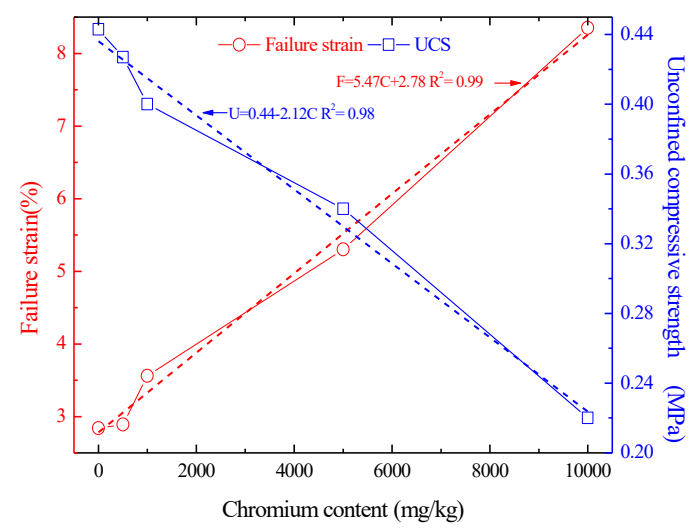

Fig. 6: Effect of chromium content on the unconfined compression strength and failure strain of soil. 
Where $\mathrm{C}$ is the soil $\mathrm{Cr}(\mathrm{VI})$ content, $\varepsilon_{\mathrm{fc}}$ is the failure strain of the soil with $\mathrm{Cr}(\mathrm{VI})$ content, $\varepsilon_{0}$ is the failure strain of the $\mathrm{Cr}(\mathrm{VI})$-free soils and is set to $2.78 \%$ in this paper, $\mathrm{q}_{0}$ is the unconfined compressive strength of the $\mathrm{Cr}(\mathrm{VI})$-free soil soils and is set to $0.44 \mathrm{MPa}$ in this paper, and $\mathrm{q}_{\mathrm{uc}}$ is the unconfined compressive strength of the soils with $\mathrm{Cr}(\mathrm{VI})$ content.

The changes in the strength properties of the soil could also be attributed to the $\mathrm{Cr}(\mathrm{VI})$ brought about by the aggregation of soil particles, which lowered the cementing strength between the soil particles and reduced the stability of the soil (Zha et al. 2014). Chen et al. (2014) found that the $\mathrm{q}_{\mathrm{u}}$ of soil contaminated with $10000 \mathrm{mg} / \mathrm{kg}$ and $50000 \mathrm{mg} / \mathrm{kg} \mathrm{Pb}$ was $15 \%$ and $50 \%$ lower than that of natural soil, respectively. Therefore, $\mathrm{Cr}(\mathrm{VI})$ considerably degraded the mechanical properties of the soil with respect to $\mathrm{Pb}$.

\section{Permeability}

Fig. 7 shows the hydraulic conductivity of soil with different $\mathrm{Cr}(\mathrm{VI})$ contents. As the $\mathrm{Cr}(\mathrm{VI})$ content increased from $0 \mathrm{mg} /$ $\mathrm{kg}$ to $10000 \mathrm{mg} / \mathrm{kg}$, the hydraulic conductivity of the samples changed from $2.1 \times 10^{-8} \mathrm{~cm} / \mathrm{s}$ to $1.5 \times 10^{-7} \mathrm{~cm} / \mathrm{s}$, which could be attributed to the reduced DDL thickness resulting from the aggregation of soil particles and shrinkage of soil clusters. Shrinkage can result in cracking and greatly increase hydraulic conductivity (Jo et al. 2005).

\section{Shear Strength}

The effect of $\mathrm{Cr}(\mathrm{VI})$ content on the shear strength of the soil is shown in Fig. 8 and Table 1. The shear strength and cohesion of the soil decreased along with an increasing $\mathrm{Cr}(\mathrm{VI})$ content and decreasing angle of internal friction. $\mathrm{Cr}(\mathrm{VI})$ can decrease the shear strength of soil mainly due to its degrading effects on cohesion. The aggregation of soil particles reduced the amount of soil contact points, thereby allowing the soil particles to move freely and decreasing both

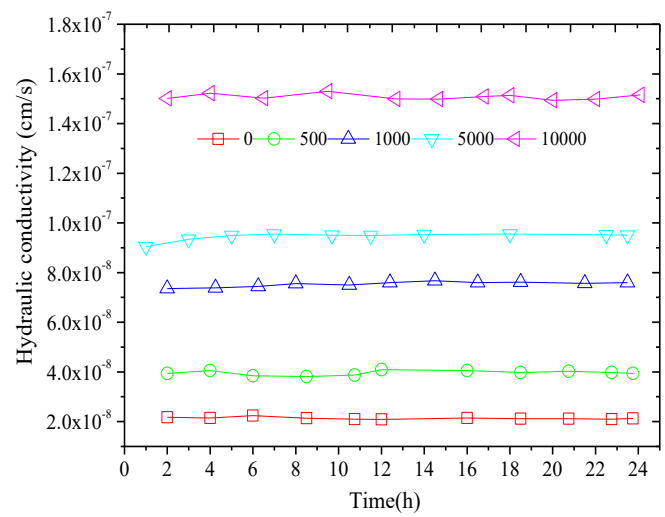

Fig. 7: Effect of chromium content on the hydraulic conductivity of the soil.

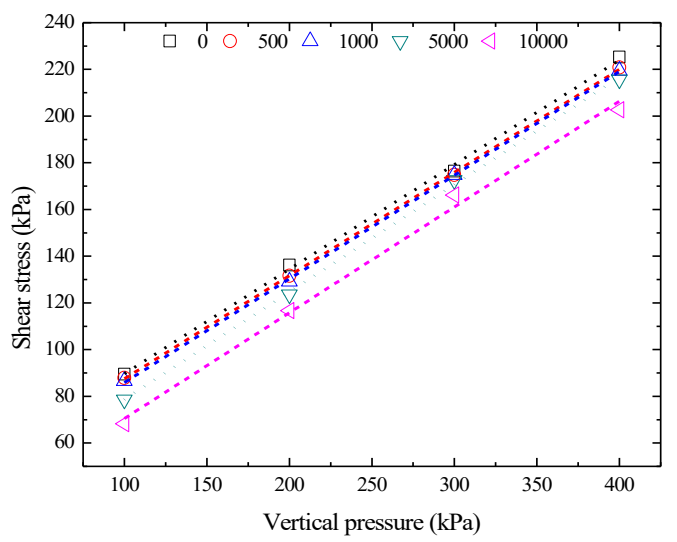

Fig. 8: Effect of chromium content on the shear strength of the soil.

Table 1: Effect of chromium content on the cohesion and angle of internal friction of soil.

\begin{tabular}{|lll|}
\hline $\begin{array}{l}\text { Chromium content } \\
(\mathrm{mg} / \mathrm{kg})\end{array}$ & Cohesion $(\mathrm{kPa})$ & Angle of internal friction \\
\hline 0 & 45.92 & $23.12^{\circ}$ \\
500 & 43.91 & $23.35^{\circ}$ \\
1000 & 41.48 & $23.55^{\circ}$ \\
5000 & 35.63 & $23.82^{\circ}$ \\
10000 & 25.19 & $24.76^{\circ}$ \\
\hline
\end{tabular}

shear strength and internal friction. Cho et al. (2007) reported that the internal friction angle of soil is closely related to the shape of soil particles and that friction angle increases along with the irregularity of soil particles. By changing the soil grain size distribution and increasing the irregularity of soil particles, $\mathrm{Cr}(\mathrm{VI})$ increased the friction angle.

\section{Nitrogen Adsorption}

The effect of $\mathrm{Cr}(\mathrm{VI})$ content on the surface area and mean pore size of the soil is shown in Fig. 9. $\mathrm{Cr}(\mathrm{VI})$ increased the

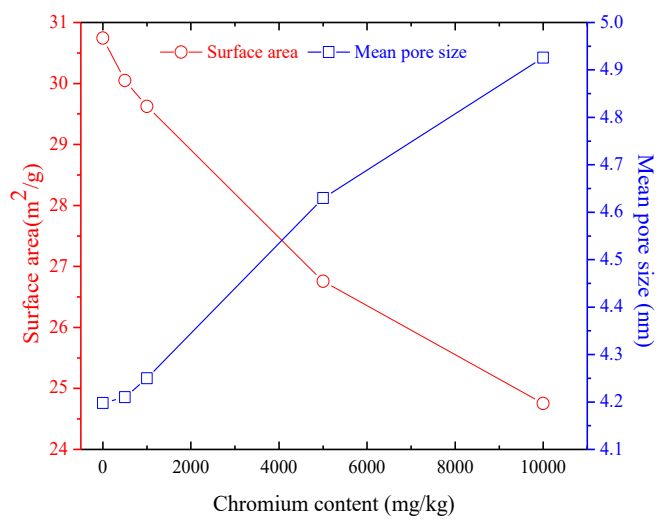

Fig. 9: Effect of chromium content on surface area and mean pore size of soil. 


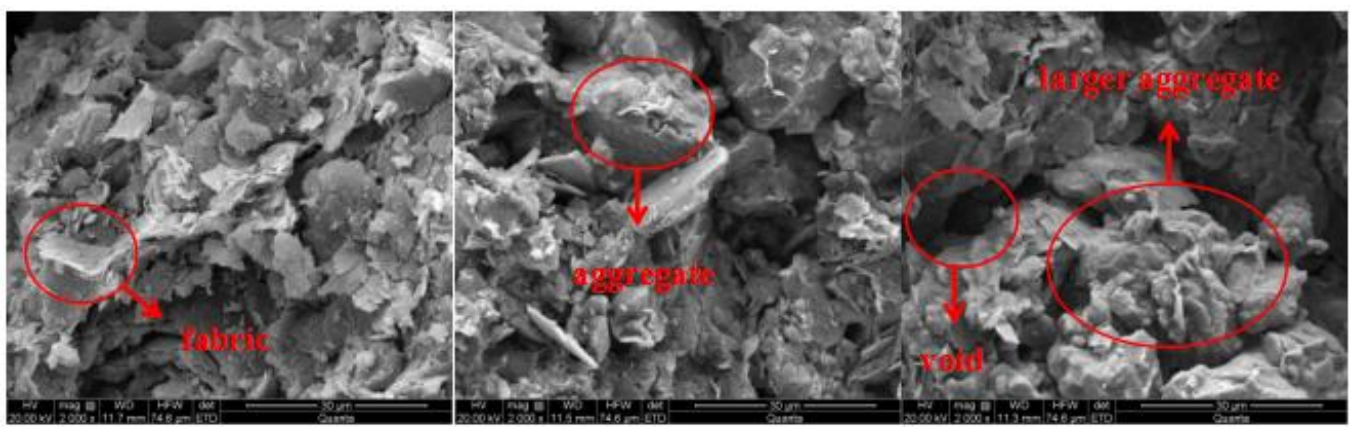

$0 \mathrm{mg} / \mathrm{kg}$

$5000 \mathrm{mg} / \mathrm{kg}$

$10000 \mathrm{mg} / \mathrm{kg}$

Fig. 10: Effect of chromium content on SEM pictures of soil.

mean pore size of the soil from $4.2 \mathrm{~nm}$ to $5.9 \mathrm{~nm}$ and reduced the surface area from $30.7 \mathrm{~m}^{2} / \mathrm{g}$ to $24.8 \mathrm{~m}^{2} / \mathrm{g}$ by aggregating the soil particles and shrinking the soil clusters. Therefore, a change in soil porosity could increase the void ratio, which in turn could increase the soil permeation rate.

\section{SEM Observations Analysis}

Fig. 10 shows the SEM images of soil samples with different Cr(VI) contents. The Cr(VI)-free soil generally had small particles with compact fabric forms. These particles mainly demonstrated a plane-to-plane contact and had many small pores. The soil with a $\mathrm{Cr}(\mathrm{VI})$ content of $5000 \mathrm{mg} / \mathrm{kg}$ had an aggregate structure and large particles with point-to-surface or edge-to-surface contact form. Meanwhile, the soil with a $\mathrm{Cr}(\mathrm{VI})$ content of $10000 \mathrm{mg} / \mathrm{kg}$ had a large aggregation formation and particles with point-to-surface or edge-tosurface contact forms separated by large void space. These SEM images highlight the variations in the particle size and permeability test results of different soil samples and altogether suggest that $\mathrm{Cr}(\mathrm{VI})$ could lead to the aggregation of soil particles, changes in the internal structure of the soil, and differences in mechanical behaviours.

\section{XRD Patterns Analysis}

Fig. 11 shows the XRD patterns of soil samples with different $\mathrm{Cr}(\mathrm{VI})$ contents. The major phases in the $\mathrm{Cr}(\mathrm{VI})$-free soil were quartz, albite, illite, and montmorillonite, while the soil with $10000 \mathrm{mg} / \mathrm{kg} \mathrm{Cr}(\mathrm{VI})$ only had calcite, thereby suggesting that $\mathrm{Cr}(\mathrm{VI})$ could also trigger clay mineral disintegrations. Li et al. (2015) and Ouhadi et al. (2006) suggested that heavy metals can convert clay minerals (kaolinite+illite+montmorillonite) into calcite and illite due to the ion exchange reactions among sodium, calcium magnesium, aluminium, and chromium ions. Meanwhile,
Shear et al. (1993) found that the mechanical properties of soil are greatly influenced by the clay mineral content in the soil. The reduction in clay content was in line with the results of the unconfined compression strength and shear tests.
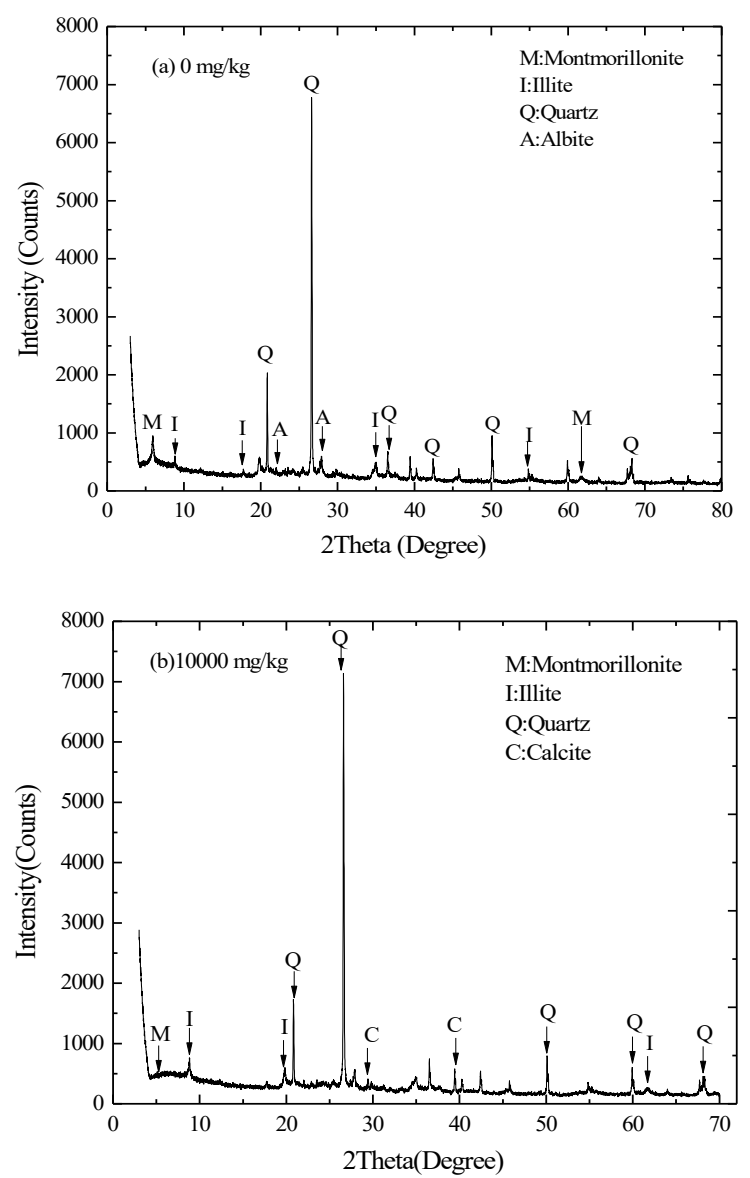

Fig. 11: XRD patterns of soil with different $\mathrm{Cr}(\mathrm{VI})$ content. 


\section{CONCLUSIONS}

This study explores the effect of $\mathrm{Cr}(\mathrm{VI})$ on the engineering and microstructure properties of Chinese clay. The following conclusions can be drawn from the results:

1. $\mathrm{Cr}(\mathrm{VI})$ changes the physicochemical properties of soil. Specifically, $\mathrm{Cr}(\mathrm{VI})$ decreases the $\mathrm{pH}$ and optimum moisture content of the soil, and an increasing $\mathrm{Cr}(\mathrm{VI})$ content can increase the specific gravity, particle size, and maximum dry density of the soil.

2. $\mathrm{Cr}(\mathrm{VI})$ degrades the mechanical properties of soil. Specifically, an increasing $\mathrm{Cr}(\mathrm{VI})$ content corresponds to reductions in unconfined compression strength and shear strength, higher hydraulic conductivity, lower soil cohesion, and increased angle of internal friction.

3. $\mathrm{Cr}(\mathrm{VI})$ changes the microstructure and engineering properties of soil. According to the BET test results, an increase in $\mathrm{Cr}(\mathrm{VI})$ corresponds to an increase in the mean pore size of the soil. The SEM images show that the $\mathrm{Cr}(\mathrm{VI})$-contaminated soil has an aggregate structure with a large void space, whereas the XRD images show that $\mathrm{Cr}(\mathrm{VI})$ changes the mineral composition of the soil and converts clay minerals (kaolinite+illite+montmorillonite) into calcite.

\section{ACKNOWLEDGMENTS}

This study was supported by the thirteenth 3551 talent program of China optical valley (long-term innovative of Ting Ting Zhang),National Natural Science Foundation of Shandong province (ZR2020QE148), Natural Science Foundation of Qingdao University of Technology (2018TJZR002, 2019ZR007) and University research project of Shandong Province (J18KB059).

\section{REFERENCES}

Cheng, F. and Wang, X. 2014. Effects of mass ratio of heavy metal on geotechnical properties of contaminated soil. Mining and Metallurgical Engineering, 34(5): 14-18.

Cho, G.C., Dodds, J. and Santamarina, J.C. 2007. Closure to particle shape effects on packing density, stiffness, and strength: natural and crushed sands. Journal of Geotechnical and Geoenvironmental Engineering, 133(11): 1474-1474.

Du, Y.J., Jiang, N.J. and Liu, S.Y. 2013. Engineering properties and microstructural characteristics of cement-stabilized zinc-contaminated kaolin. Canadian Geotechnical Journal, 51(3): 289-302.
Horpibulsk, S., Rachan, R., Suddeepong, A. and Chinkulkijniwat, A. 2011. Strength development in cement admixed Bangkok clay: laboratory and field investigations. Soils and Foundations, 51(2): 239-251.

Jo, H.Y., Benson, C.H., Shackelford, C.D., Lee, J.M. and Edil, T.B. 2005. Long-term hydraulic conductivity of a geosynthetic clay liner permeated with inorganic salt solutions. Journal of Geotechnical and Geoenvironmental Engineering, 131(4): 405-417.

Li, J., Xue, Q. and Wang, P. 2015. Effect of lead (II) on the mechanical behavior and microstructure development of a Chinese clay. Applied Clay Science, 105: 192-199.

Liu, Z.B., Fang, W., Chen, Z. L. and YU, C. 2016. Experimental study of influence of zinc ions on one-dimensional compressibility of bentonite. Rock and Soil Mechanics, 8: 2211-2217, 2013.

Miranda-Trevino, J.C. and Coles, C.A. 2003. Kaolinite properties, structure and influence of metal retention on $\mathrm{pH}$. Applied Clay Science, 23(1-4): 133-139.

Morvan, M., Espinat, D., Lambard, J. and Zemb, T. 1994. Ultrasmall-and small-angle X-ray scattering of smectite clay suspensions. Colloids and Surfaces A: Physicochemical and Engineering Aspects, 82(2): 193-203.

Ouhadi, V.R. and Goodarzi, A.R. 2006. Assessment of the stability of a dispersive soil treated by alum. Engineering Geology, 85(1-2): 91-101.

Shear, D.L., Olsen, H.W. and Nelson, K.R. 1992. Effects of desiccation on the hydraulic conductivity versus void ratio relationship for a natural clay. Transportation Research Record 1369, pp. 130-135.

Standard for Soil Test Method, 50123. 1999. Ministry of Housing and Urban-Rural Development of the People's Republic of China, Beijing, China.

Turer, D. 2007. Effect of heavy metal and alkali contamination on the swelling properties of kaolinite. Environmental Geology, 52(3): 421.

Wei, M.L., Du, Y.J., Reddy, K.R. and Wu, H.L. 2015. Effects of freezethaw on characteristics of new KMP binder stabilized $\mathrm{Zn}$-and $\mathrm{Pb}$ contaminated soils. Environmental Science and Pollution Research, 22(24): 19473-19484.

Wang, Y., Fang, Z., Liang, B. and Tsang, E.P. 2014. Remediation of hexavalent chromium contaminated soil by stabilized nanoscale zero-valent iron prepared from steel pickling waste liquor. Chemical Engineering Journal, 247: 283-290.

Wu, H. and Hu, L. 2014. Microfabric change of electro-osmotic stabilized bentonite. Applied Clay Science, 101: 503-509.

Zha, F.S., Liu, J.J. and Xia, L. 2014. Engineering properties of heavy metal contaminated soil. Chinese Journal of Underground Space and Engineering, 10(2): 1982-1985.

Zhang, D., Kong, H., Wu, D., He, S., Hu, Z. and Hu, X. 2009. Remediation of chromite ore processing residue by pyrolysis process with sewage sludge. Bioresource Technology, 100(11): 2874-2877.

Zhang, T.T., Xue, Q. and Li, J.S. 2019. Effect of ferrous sulfate dosage and soil particle size on leachability and species distribution of chromium in hexavalent chromium contaminated soil stabilized by ferrous sulfate. Environmental Progress \& Sustainable Energy, 38(2): 500-507.

Zhang, T.T., Xue, Q. and Wei, M.L. 2018. Leachability and stability of hexavalent chromium contaminated soil stabilized by ferrous sulfate and calcium polysulfide. Applied Sciences, 8(9): 1431.

Zhang, Z.H., Li, H.Y. and Shi, Y. M. 2014. Experimental study on permeability properties and micro-structure of clay contaminated by $\mathrm{Cu}^{2+}$. China Civil Engineering Journal, 47(12): 122-129. 